\title{
SIFCON ile Üretilen Beton Yolların Bazı Mekanik Özelliklerinin Optimizasyonu
}

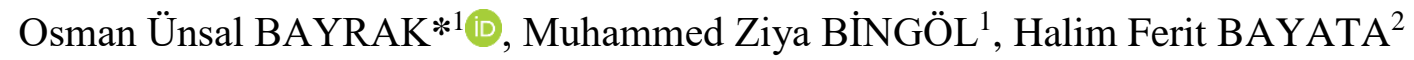 \\ ${ }^{1}$ Atatürk University, Civil Engineering Department, Erzurum, Turkey. \\ ${ }^{1}$ Atatürk University, Civil Engineering Department, Erzurum, Turkey. \\ ${ }^{3}$ Erzincan Binali Yıldırım University, Civil Engineering Department, Erzincan, Turkey. \\ Geliş / Received: 30/10/2018, Kabul / Accepted: 16/01/2019
}

\begin{abstract}
Öz
Son zamanlarda geliştirilen kompozit bir malzeme olan çimento bulamacı emdirilmiş lifli beton (SIFCON), inşaat mühendisliği alanında çok popüler malzemelerden biri olmuştur. Yüksek dayanımlı betonlardan en önemli farkı kırılma sırasında sünek davranış göstermesidir. Bu çalışmada SIFCON'un rijit kaplama olarak kullanımı araştırılmıştır. Deneyler, $\mathrm{L}_{16}$ ortogonal dizi tekniği kullanılarak her biri dört seviyeli dört faktör ile tasarlanmıştır. Faktörler ve seviyeleri 40, 55, 65, 80 lif görünüm oranı, \%3, \%6, \%9, \%12 lif hacmi, 0,30, 0,35, 0,40, 0,45 su/çimento oranı ve \%0, \%5, \%10,\%15 silis dumanı oranıdır. Deney sonuçları Taguchi yöntemi ile varyans analizi (ANOVA) tekniği kullanılarak değerlendirilmiştir. ANOVA'ya göre, beton kaplamaların basınç ve eğilme mukavemetinde en önemli rolü lif görünüm oranı (L/d) oynamıştır. Ayrıca basınç mukavemeti için optimum koşullar 55 (L/d), \%3 lif oranı, 0.45 su / bağlayıcı oranı ve \%5 SD oranı, eğilme mukavemeti için 80 L/d, \%12 lif oranı, 0.45 su / bağlayıcı oranı ve \%5 SD oranı olarak bulunmuştur. Optimum koşullarda 145.72 MPa ve 31.58 MPa'lık maksimum basınç ve eğilme dayanımı elde edilmiştir.
\end{abstract}

Anahtar Kelimeler: Beton Yollar, SIFCON, Çelik Lif, Taguchi Metodu

\section{Optimization of the Some Mechanical Properties of Concrete Pavements Produced with SIFCON}

\begin{abstract}
Abctract
Slurry Infiltrated Fiber Reinforced Concrete (SIFCON) is one of the recently developed composite material became a very popular material in civil engineering. The difference between high strength concrete (HSC) and SIFCON is the ductile behavior at failure. In this study, usage of SIFCON as a rigid pavement is investigated. The experiments were designed according to Taguchi method using orthogonal array technique in an L16 array with four factors with four levels each. The factors and their levels are 40, 55, 65, 80 fiber aspect ratio, 3\%, 6\%, $9 \%, 12 \%$ fiber volume, $0,30,0,35,0,40,0,45$ water/cement ratio $(\mathrm{w} / \mathrm{c})$ ratios and $0 \%, 5 \%, 10 \%, 15 \%$ silica fume ratio. Analysis of variance technique (ANOVA) was used for analyzing the test results. According to the ANOVA, the fiber aspect ratio (L/d) plays a significant role in compressive and flexural strength. Moreover, the optimum conditions were found to be 55 fiber aspect ratio, $3 \%$ fiber content, $0.45 \mathrm{w} / \mathrm{c}$ ratio and $5 \%$ SF ratio for compressive strength and 80 fiber aspect ratio, $12 \%$ fiber content, $0.45 \mathrm{w} / \mathrm{c}$ ratio and $5 \%$ SF ratio for flexural strength. Maximum compressive and flexural strength of 145.72 and $31.58 \mathrm{MPa}$ was obtained under the optimum conditions respectively.
\end{abstract}

Keywords: Concrete Pavements, SIFCON, Steel Fiber, Taguchi Method

\section{Introduction}

Concrete roads are rigid pavements that are more environmentally friendly compared to flexible pavements and have a long service life and resistance to heavy vehicle loads. Although it has many advantages, concrete which is a brittle material, is generally poor in terms of fatigue strength, abrasion resistance, flexural strength, load carrying capacity after cracking (Mehta, 1986; Neville, 1995). Particularly dynamic wheel 
loads cause cracks in the corner and the edge of concrete with low flexural strength and these cracks spread easily. Adding fiber to the concrete can increase ductility and energy absorption capacity of concrete (Lee, 2017; Lee et al., 2017). Random and uniformly distributed steel fibers in concrete cause decrease significantly the formation of cracks in the concrete. ACI Committee 544 (ACI, 1996) reported that the addition of steel fibers in a concrete matrix improves all mechanical properties of concrete, especially durability, tensile strength and toughness (Musmar, 2013). Hence, concrete with high ductility level is obtained by increasing the strain capacity of the concrete and energy absorption capacity.

SIFCON is a special type of highperformance composite material. It was developed by Lankard in New Mexico Engineering Research Institute in 1984 (Lankard, 1984; Lankard and Newell, 1984). The fiber content in conventional fiber concrete is limited to $3 \%$ by volume, while $5-30 \%$ can be attained in SIFCON depending on the geometric properties of the fiber used (Tuyan ve Yazic1, 2012; Beglarigale et al., 2016). Steel fibers are placed into a formwork and then flowable slurry (cement, water, silica fume, very fine sand and superplasticizer) infiltrated to coat the fibers. In SIFCON the fiber content and the fiber geometric properties influence the void size between fibers and thus the fineness of the slurry (Abdou et al., 1989). The main differences that distinguish SIFCON from steel fiber concretes are its high fiber content and the matrix of the slurry is composed of very thin materials. These two phenomena give the SIFCON superior flexural strength, toughness and ductility. SIFCON has been used in many applications such as pavement repairs, repair of bridge structures, safe vaults, defense structures, repair, and reinforcement works (Rao et al., 2010; Tuyan and Yazıc1, 2012).

In a concrete mix design, when the number of mix variables increases, the number of experiments also increases. Hence, the quantity of materials, money and time increases in the traditional design of experiments. The Taguchi method can be used to decrease the number of experiments for such experimental studies. One of the advantages of the Taguchi method over the traditional experimental design is keeping the experimental cost at a minimum level.

Flexural strength is one of the most important parameters in concrete pavement design. In this study, the effect of aspect ratio (height/thickness), fiber content, w/c ratio and silica fume (SF) content on the compressive and flexural strength of the SIFCON were investigated. This experimental work was designed to obtain the optimum working conditions of the parameters which affect the flexural and compressive strength, using the Taguchi method.

\section{Materials and Method}

In this study, Portland cement (CEM I 42.5 $\mathrm{R})$ was used. The pozzolanic material is required for filling the voids of microparticulates in the binder paste. This pozzolanic material contributes the binder paste strength by its pozzolanic reaction (Richard and Cheyrezy, 1995; Chan and Chu, 2004; Hinislioglu and Bayrak, 2004). Therefore, SF obtained from Electro Metallurgy Enterprise was used in this study. The physical and chemical properties of the cement and SF are summarized in Table 1. 
Table 1. Chemical and physical properties of PC and SF

\begin{tabular}{|c|c|c|c|}
\hline Component & & $\mathrm{PC}(\%)$ & SF (\%) \\
\hline Unit volume weight $(\mathrm{g} / \mathrm{mL})$ & & 3.13 & - \\
\hline Specific surface $\left(\mathrm{cm}^{2} / \mathrm{g}\right)$ & & 3690 & - \\
\hline Specific gravity & & 3.12 & - \\
\hline Initial setting time (min) & & 130 & - \\
\hline Final setting time (min) & & 195 & - \\
\hline Volume expansion (mm) & & 1 & - \\
\hline \multirow{3}{*}{ Compressive Strength (MPa) } & 2 days & 23.5 & - \\
\hline & 7 days & 35.3 & - \\
\hline & 28 days & 47.0 & - \\
\hline \multirow{3}{*}{$\begin{array}{l}\text { Flexural Strength } \\
(\mathrm{MPa})\end{array}$} & 2 days & 5.0 & - \\
\hline & 7 days & 6.2 & - \\
\hline & 28 days & 7.7 & - \\
\hline $\mathrm{SiO}_{2}$ & & 19.94 & $85-95$ \\
\hline $\mathrm{Al}_{2} \mathrm{O}_{3}$ & & 5.28 & $1.0-3.0$ \\
\hline $\mathrm{Fe}_{2} \mathrm{O}_{3}$ & & 3.45 & $0.5-1.0$ \\
\hline $\mathrm{CaO}$ & & 62.62 & $0.8-1.2$ \\
\hline $\mathrm{MgO}$ & & 2.62 & $1-2$ \\
\hline $\mathrm{SO}_{3}$ & & 2.46 & - \\
\hline LOI & & 1.99 & $0.5-1,0$ \\
\hline $\mathrm{Na}_{2} \mathrm{O}$ & & 0.23 & 2.18 \\
\hline $\mathrm{K}_{2} \mathrm{O}$ & & 0.83 & - \\
\hline $\mathrm{Cl}$ & & 0.0107 & - \\
\hline Undetermined & & 0.08 & - \\
\hline Total & & 100 & - \\
\hline Free $\mathrm{CaO}$ & & 0.51 & - \\
\hline Insoluble residue & & 0.70 & - \\
\hline $\mathrm{Fe}_{2} \mathrm{O}_{3}$ & & 3.45 & - \\
\hline
\end{tabular}

Portland cement (CEM I 42.5 R) was added as the basic cementitious material. The dosage was kept constant at $800 \mathrm{~kg} / \mathrm{m} 3$. SF was added as partial replacement of the cement at levels of $0 \%, 5 \%, 10 \%$ and $15 \%$. The $\mathrm{w} / \mathrm{c}$ ratios were $0.30,0.35,0.40$ and 0.45 . The dosage level of polycarboxylate based superplasticiser was slightly adjusted for mixes to maintain the adequate workability. Steel fibers (Figure 1) with hooked-end were used at levels of $3 \%$, $6 \%, 9 \%$ and $12 \%$ with four different aspect

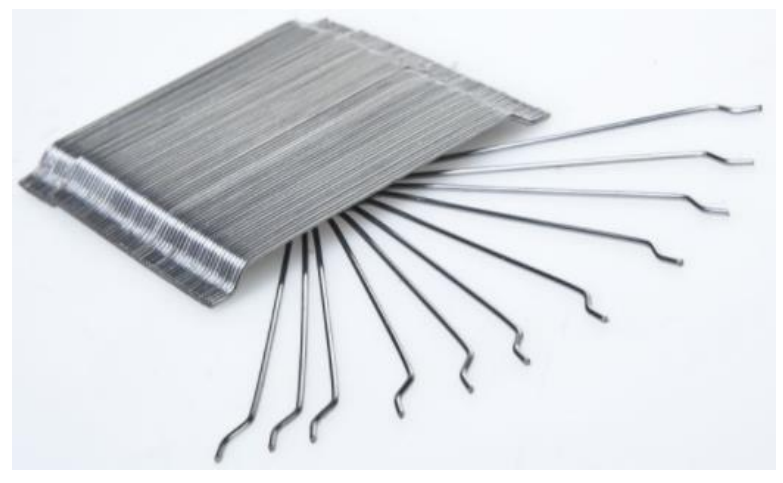

Figure 1. Hooked-end steel fibers ratios (L/d) of 40, 55, 65 and 80 . The physical and mechanical properties of the fibers are presented in Table 2. 
Table 2. Properties of Hooked-end steel fibers

\begin{tabular}{lcccc}
\hline Fiber Type & $\begin{array}{c}\text { KMX } \\
(\mathbf{L} / \mathbf{d})\end{array}$ & $\begin{array}{c}\text { KMX } \\
(\mathbf{L} / \mathbf{d})\end{array}$ & $\begin{array}{c}\text { KMX } \\
(\mathbf{L} / \mathbf{d})\end{array}$ & $\begin{array}{c}\text { KMX } \\
(\mathbf{L} / \mathbf{d})\end{array}$ \\
\hline Length (L) (mm) & $\mathbf{4 0 / 3 0}$ & $\mathbf{5 5 / 3 0}$ & $\mathbf{6 5 / 3 5}$ & $\mathbf{8 0 / 6 0}$ \\
\hline Diameter (d) (mm) & 30 & 30 & 35 & 60 \\
Aspect ratio (L/d) & 0,75 & 0,55 & 0,55 & 0,75 \\
Min. Tensile Strength $\left(\mathrm{N} / \mathrm{mm}^{2}\right)$ & 40 & 55 & 65 & 80 \\
\hline
\end{tabular}

Two $150 \times 150$ x $150 \mathrm{~mm}$ cube and 7 x 7 x 28 $\mathrm{mm}$ beams were cast for each mix. The specimens were demolded after $24 \mathrm{~h}$ and stored in a water tank at $21 \pm 1^{\circ} \mathrm{C}$ until tested at 28 days. Then the compressive and flexural strengths of each specimen were determined.

\subsection{Experimental approach}

In full factorial experiment design, one factor is varied while all other factors are kept constant. The number of experiments will increase as the factors and levels in the design of the experiment increase. Therefore, it will not be possible to perform such a design in practice. Moreover, if interactions between the parameters are present, the optimum condition obtained from the conventional experimental design may not be the actual optimum. The fractional factorial experiments using an orthogonal array were investigated and developed by Taguchi. The linear graph developed by Taguchi is useful to scientists and engineers to design and analyze the experimental data without having the basic knowledge of factorial design (Taguchi, 1962; Roy, 1990; Hinislioglu and Bayrak, 2004; Bayrak and Hinislioglu, 2017).

The experiments were designed according to the orthogonal array technique. Factors and their levels were selected based on the literature review on the subject. Four factors with four levels each have been taken for experimental design. The $\mathrm{L}_{16}$ orthogonal array was selected according to Taguchi Method (Table 3).

Table 3. Factors and their levels

\begin{tabular}{lrrrr}
\hline \multirow{2}{*}{ Factors } & \multicolumn{4}{c}{ Levels } \\
\cline { 2 - 5 } & \multicolumn{1}{c}{$\mathbf{1}$} & \multicolumn{1}{c}{$\mathbf{3}$} & \multicolumn{4}{c}{} \\
\hline (A) Aspect ratio (L/d) & $40\left(\mathbf{A}_{1}\right)$ & $55\left(\mathbf{A}_{2}\right)$ & $60\left(\mathbf{A}_{3}\right)$ & $80\left(\mathbf{A}_{4}\right)$ \\
(B) Fiber Ratio (\%) & $3\left(\mathbf{B}_{1}\right)$ & $6\left(\mathbf{B}_{2}\right)$ & $9\left(\mathbf{B}_{3}\right)$ & $12\left(\mathbf{B}_{4}\right)$ \\
(C) w/c & $0.30\left(\mathbf{C}_{1}\right)$ & $0.35\left(\mathbf{C}_{2}\right)$ & $0.40\left(\mathbf{C}_{3}\right)$ & $0.45\left(\mathbf{C}_{4}\right)$ \\
(D) SF Ratio (\%) & $0\left(\mathbf{D}_{1}\right)$ & $5\left(\mathbf{D}_{2}\right)$ & $10\left(\mathbf{D}_{3}\right)$ & $15\left(\mathbf{D}_{4}\right)$ \\
\hline
\end{tabular}


The experiments were carried out based on the $\mathrm{L}_{16}$ orthogonal array by the Taguchi method Table 4.

Table 4. $\mathrm{L}_{16}$ orthogonal array

\begin{tabular}{ccccc}
\hline $\begin{array}{c}\text { Experim } \\
\text { ent } \\
\text { Number }\end{array}$ & $\begin{array}{c}\text { Aspe } \\
\text { ct } \\
\text { ratio } \\
\text { (L/d) }\end{array}$ & $\begin{array}{c}\text { Fiber } \\
\text { Ratio } \\
(\%)\end{array}$ & W/C & $\begin{array}{c}\text { SF } \\
\text { \%) }\end{array}$ \\
\hline 1 & 1 & 1 & 1 & 1 \\
2 & 1 & 2 & 2 & 2 \\
3 & 1 & 3 & 3 & 3 \\
4 & 1 & 4 & 4 & 4 \\
5 & 2 & 1 & 2 & 3 \\
6 & 2 & 2 & 1 & 4 \\
7 & 2 & 3 & 4 & 1 \\
8 & 2 & 4 & 3 & 2 \\
9 & 3 & 1 & 3 & 4 \\
10 & 3 & 2 & 4 & 3 \\
11 & 3 & 3 & 1 & 2 \\
12 & 3 & 4 & 2 & 1 \\
13 & 4 & 1 & 4 & 2 \\
14 & 4 & 2 & 3 & 1 \\
15 & 4 & 3 & 2 & 4 \\
16 & 4 & 4 & 1 & 3 \\
\hline
\end{tabular}

The numbers in Table 4 represent the levels of each factor for the related experiment. The order of experiments was carried out randomly to avoid noise sources which had not been initially considered and affect the results in a negative way. The test results were calculated based on the quality characteristic of "the bigger the best" by equation 1 .

$S / N_{L}=-10 \log \left[\frac{1}{n} \sum_{1}^{n} \frac{1}{Y_{i}^{2}}\right]$

Here, $\mathrm{S} / \mathrm{N}$ is the performance statistics, defined as the signal to noise ratio ( $\mathrm{S} / \mathrm{N}$ unit: $\mathrm{dB}), \mathrm{n}$ is the number of the repetition for each experiment and $\mathrm{Y}_{\mathrm{i}}$ is the performance value of the $\mathrm{i}$ th experiment.

The levels of factors that maximize the $\mathrm{S} / \mathrm{N}$ were optimum. However, in the Taguchi method, the experiment corresponding to the optimum working conditions might not have been done during the whole period of the experimental stage. In such cases, the performance value corresponding to the optimum working conditions can be predicted by the balanced character of the orthogonal array using the following equation:

$Y_{i}=\mu+X_{i}+e_{i}$

where $\mu$ is the overall mean of the performance value, $X_{i}$ is the fixed effect of the factor level combination used in the ith experiment and $\mathrm{e}_{\mathrm{i}}$ is the random error in the $\mathrm{i}$ th experiment. Because Equation (2) is a point estimation, which is calculated by using experimental data in order to determine whether results of the confirmation experiments are meaningful or not, the confidence interval must be evaluated. The confidence interval at the chosen error level may be calculated by the following equation:

$C I=\mu \pm \sqrt{\frac{F\left(1, n_{2}\right)}{N_{e}}}$

where $\mu$ is the overall mean of the performance value at optimum conditions, $\mathrm{F}$ is the value of the $\mathrm{F}$ table, $\mathrm{Ne}$ is the effective number of repetition in confirmation analysis (Hinislioglu and Bayrak, 2004, 2005; Bayrak and Hinislioglu, 2017).

\section{Results and Discussion}

The compressive and flexural strengths obtained from experiments are given in Table 5 together with their equivalent $\mathrm{S} / \mathrm{N}$ values (Bingöl, 2017). 
Table 5. Orthogonal array for $\mathrm{L}_{16}$ with test results

\begin{tabular}{|c|c|c|c|c|c|c|c|c|c|c|}
\hline \multirow{3}{*}{$\begin{array}{c}\begin{array}{c}\text { Experiment } \\
\text { Number }\end{array} \\
1\end{array}$} & \multirow{3}{*}{$\begin{array}{c}\begin{array}{c}\text { Aspect } \\
\text { ratio } \\
\text { (l/d) }\end{array} \\
\mathrm{A}_{1}\end{array}$} & \multirow{3}{*}{$\begin{array}{c}\begin{array}{c}\text { Fiber } \\
\text { Ratio } \\
(\%)\end{array} \\
\mathrm{B}_{1}\end{array}$} & \multirow{3}{*}{$\begin{array}{l}\text { w/c } \\
\mathrm{C}_{1}\end{array}$} & \multirow{3}{*}{$\begin{array}{c}\begin{array}{c}\text { SF } \\
(\%)\end{array} \\
D_{1}\end{array}$} & \multicolumn{3}{|c|}{ Compressive Strength } & \multicolumn{3}{|c|}{ Flexural Strength } \\
\hline & & & & & \multicolumn{2}{|c|}{$\begin{array}{l}\text { Test Results } \\
\text { (MPa) }\end{array}$} & \multirow{2}{*}{$\begin{array}{c}\begin{array}{c}\text { Performance } \\
\text { Statistics } \\
(\mathbf{S} / \mathbf{N})\end{array} \\
35,518\end{array}$} & \multicolumn{2}{|c|}{$\begin{array}{l}\text { Test Results } \\
\text { (MPa) }\end{array}$} & \multirow{2}{*}{$\begin{array}{c}\begin{array}{c}\text { Performanc } \\
\text { Statistics } \\
(\mathbf{S} / \mathbf{N})\end{array} \\
17.177\end{array}$} \\
\hline & & & & & 60.23 & 59.15 & & 6.85 & 7.60 & \\
\hline 2 & $\mathrm{~A}_{1}$ & $\mathrm{~B}_{2}$ & $\mathrm{C}_{2}$ & $\mathrm{D}_{2}$ & 50.95 & 51.49 & 34,189 & 10.14 & 11.75 & 20.784 \\
\hline 3 & $\mathrm{~A}_{1}$ & $\mathrm{~B}_{3}$ & $\mathrm{C}_{3}$ & $\mathrm{D}_{3}$ & 63.33 & 62.48 & 35,974 & 11.25 & 10.26 & 20.632 \\
\hline 4 & $\mathrm{~A}_{1}$ & $\mathrm{~B}_{4}$ & $\mathrm{C}_{4}$ & $\mathrm{D}_{4}$ & 53.79 & 52.74 & 34,529 & 15.21 & 14.38 & 23.401 \\
\hline 5 & $\mathrm{~A}_{2}$ & $\mathrm{~B}_{1}$ & $\mathrm{C}_{2}$ & $\mathrm{D}_{3}$ & 80.46 & 78.51 & 38,006 & 18.45 & 17.62 & 25.122 \\
\hline 6 & $\mathrm{~A}_{2}$ & $\mathrm{~B}_{2}$ & $\mathrm{C}_{1}$ & $\mathrm{D}_{4}$ & 78.06 & 77.19 & 37,800 & 20.17 & 20.95 & 26.260 \\
\hline 7 & $\mathrm{~A}_{2}$ & $\mathrm{~B}_{3}$ & $\mathrm{C}_{4}$ & $\mathrm{D}_{1}$ & 60.15 & 59.11 & 35,509 & 19.76 & 18.52 & 25.639 \\
\hline 8 & $\mathrm{~A}_{2}$ & $\mathrm{~B}_{4}$ & $\mathrm{C}_{3}$ & $\mathrm{D}_{2}$ & 74.84 & 72.67 & 37,356 & 22.45 & 22.17 & 26.970 \\
\hline 9 & $\mathrm{~A}_{3}$ & $\mathrm{~B}_{1}$ & $\mathrm{C}_{3}$ & $\mathrm{D}_{4}$ & 71.04 & 70.59 & 37,003 & 18.92 & 18.66 & 25.479 \\
\hline 10 & $\mathrm{~A}_{3}$ & $\mathrm{~B}_{2}$ & $\mathrm{C}_{4}$ & $\mathrm{D}_{3}$ & 58.52 & 59.10 & 35,389 & 23.52 & 22.75 & 27.285 \\
\hline 11 & $\mathrm{~A}_{3}$ & $\mathrm{~B}_{3}$ & $\mathrm{C}_{1}$ & $\mathrm{D}_{2}$ & 43.76 & 44.24 & 32,869 & 21.76 & 22.01 & 26.803 \\
\hline 12 & $\mathrm{~A}_{3}$ & $\mathrm{~B}_{4}$ & $\mathrm{C}_{2}$ & $\mathrm{D}_{1}$ & 24.49 & 23.79 & 27,655 & 17.24 & 18.21 & 24.972 \\
\hline 13 & $\mathrm{~A}_{4}$ & $\mathrm{~B}_{1}$ & $\mathrm{C}_{4}$ & $\mathrm{D}_{2}$ & 63.15 & 61.76 & 35,911 & 25.27 & 24.62 & 27.939 \\
\hline 14 & $\mathrm{~A}_{4}$ & $\mathrm{~B}_{2}$ & $\mathrm{C}_{3}$ & $\mathrm{D}_{1}$ & 20.24 & 21.42 & 26,374 & 16.15 & 17.14 & 24.426 \\
\hline 15 & $\mathrm{~A}_{4}$ & $\mathrm{~B}_{3}$ & $\mathrm{C}_{2}$ & $\mathrm{D}_{4}$ & 14.49 & 15.21 & 23,435 & 19.53 & 18.64 & 25.614 \\
\hline \multirow[t]{2}{*}{16} & $\mathrm{~A}_{4}$ & $\mathrm{~B}_{4}$ & $\mathrm{C}_{1}$ & $\mathrm{D}_{3}$ & 21.28 & 19.52 & 26,193 & 26.25 & 27.02 & 28.509 \\
\hline & & & & & \multicolumn{2}{|c|}{ Average } & $\mathbf{3 3 , 3 5 7}$ & & & 24.813 \\
\hline
\end{tabular}

An example calculation of $\mathrm{S} / \mathrm{N}$ (the first $\mathrm{S} / \mathrm{N}$ alue of compressive strength) is as follows.

$$
\begin{aligned}
\frac{S}{N}=-10 \log & \left(\frac{1}{2}\left(\frac{1}{60.23^{2}}+\frac{1}{59.15^{2}}\right)\right) \\
& =35.518
\end{aligned}
$$

All results can be converted to $\mathrm{S} / \mathrm{N}$ with the same method. After calculating all $\mathrm{S} / \mathrm{N}$ values, the optimum conditions can be obtained by using average $\mathrm{S} / \mathrm{N}$ effects. The average $\mathrm{S} / \mathrm{N}$ effects for compressive and flexural strength are given in Table 6.

\begin{tabular}{|c|c|c|c|c|c|c|c|c|}
\hline \multirow[b]{2}{*}{ Level } & \multicolumn{4}{|c|}{ Compressive Strength } & \multicolumn{4}{|c|}{ Flexural Strength } \\
\hline & $\begin{array}{c}\text { Aspect } \\
\text { ratio } \\
\text { (1/d) }\end{array}$ & $\begin{array}{c}\text { Fiber Ratio } \\
(\%)\end{array}$ & w/c & $\begin{array}{l}\text { SF } \\
(\%)\end{array}$ & $\begin{array}{c}\text { Aspect } \\
\text { ratio } \\
(\mathbf{l} / \mathbf{d})\end{array}$ & $\begin{array}{c}\text { Fiber } \\
\text { Ratio } \\
(\%)\end{array}$ & $\mathbf{w} / \mathbf{c}$ & $\begin{array}{l}\text { SF } \\
(\%)\end{array}$ \\
\hline 1. Level & 35.052 & 36.609 & 33.095 & 31.264 & 20.498 & 23.929 & 24.687 & 23.053 \\
\hline 2. Level & 37.168 & 33.438 & 30.821 & 35.081 & 25.998 & 24.689 & 24.123 & 25.624 \\
\hline 3. Level & 33.229 & 31.947 & 34.176 & 33.890 & 26.135 & 24.672 & 24.376 & 25.387 \\
\hline 4. Level & 27.978 & 31.433 & 35.335 & 33.191 & 26.622 & 25.963 & 26.066 & 25.188 \\
\hline
\end{tabular}

Table 6. Average $\mathrm{S} / \mathrm{N}$ effects of compressive and flexural strength 
Table 6 was calculated according to the Table 5. For instance, in Table, let us choose the first level of the aspect ratio for compressive strength. The first level of aspect ratio $(\mathrm{L} / \mathrm{d}=40)$ was used in the first, second, third and fourth experiments (Table 4 and 5). The average of the $\mathrm{S} / \mathrm{N}$ values of these experiments was calculated and the value of 35.052 was written in Table 6. Likewise, the first level of SF was used in the experiment number of 1, 7, 12 and 14. Therefore, the mean effect of SF on the compressive strength
(31.264) was obtained by taking the average of the $\mathrm{S} / \mathrm{N}$ values of the experiments with numbers 1, 7, 12 and 14. All data were calculated according to the above calculation method.

In Table 6, the level which has the maximum average $\mathrm{S} / \mathrm{N}$ effect is the optimum level of that factor. Thus, the optimum conditions determined from Table 6 for compressive and flexural strength were demonstrated in Figure 2 and 3.

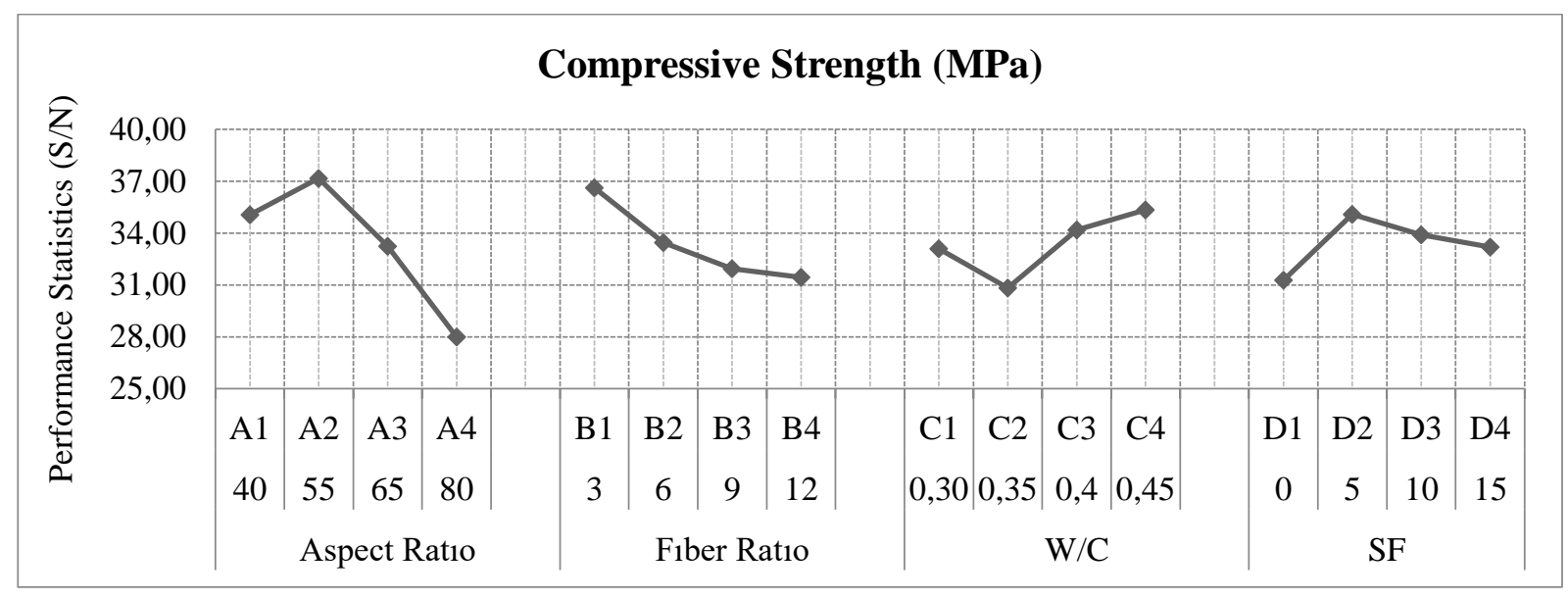

Figure 2. The effect of parameters on $\mathrm{S} / \mathrm{N}$ for compressive strength

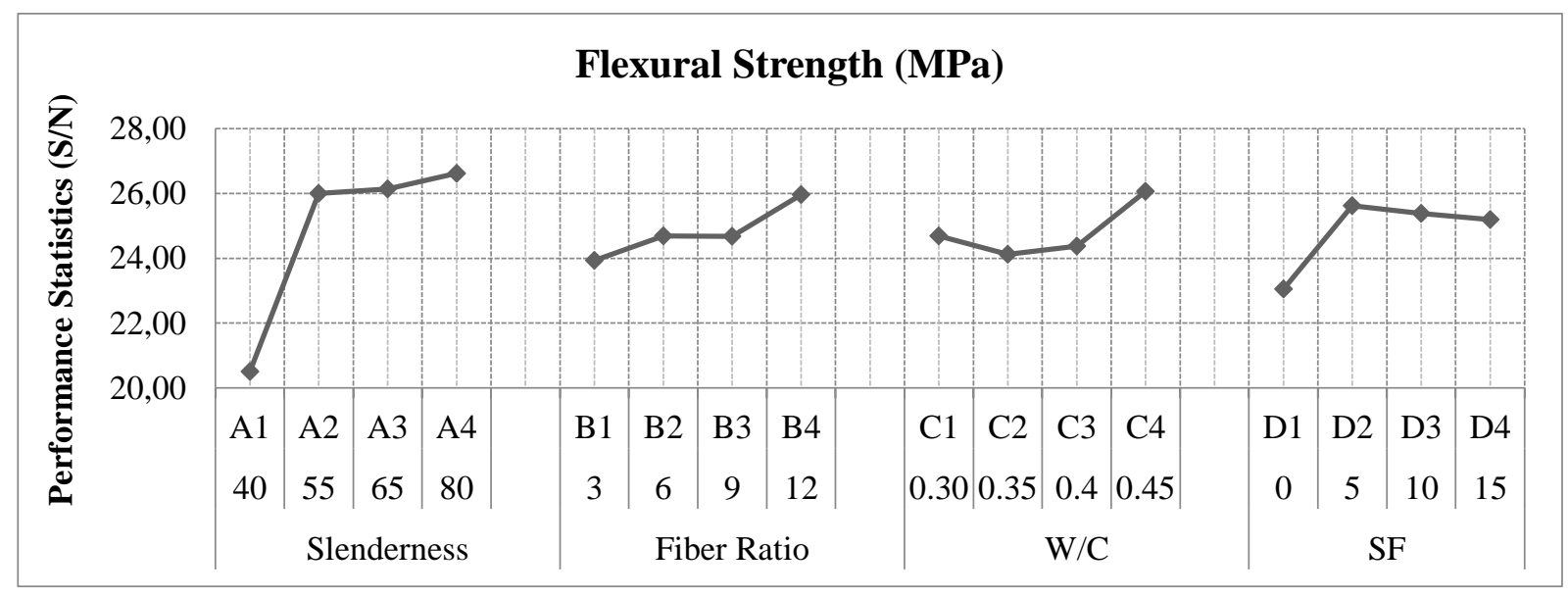

Figure 3. The effect of parameters on $\mathrm{S} / \mathrm{N}$ for flexural strength 


\subsection{Evaluation of Analysis of Variance (ANOVA)}

The quantities such as the degree of freedom (DOF), the sum of squares etc. can be calculated by ANOVA (Table 7 and 8). Moreover, the relative significance of each factor can also be calculated by ANOVA.

Table 7. The ANOVA table for compressive strength

\begin{tabular}{lcccccc}
\hline \multicolumn{1}{c}{ Factors } & DOF & $\begin{array}{r}\text { Sums of } \\
\text { Squares }\end{array}$ & Variance & F-Ratio & Pure Sum & Percent (P) \\
\hline (A) Aspect ratio & 3 & 185.380 & 61.793 & 34.752 & 180.052 & 54.43 \\
(B) Fiber Ratio & 3 & 65.100 & 21.700 & 12.198 & 59.772 & 18.07 \\
(C) W/C & 3 & 44.329 & 14.776 & 8.298 & 39.001 & 11.79 \\
(D) SF & 3 & 30.660 & 10.220 & 5.738 & 25.332 & 7.66 \\
Error & 3 & 5.328 & 1.776 & & & 8.05 \\
Total & 15 & 330.797 & & & & 100.00 \\
\hline
\end{tabular}

Table 8. The ANOVA table for flexural strength

\begin{tabular}{lcccccc}
\hline \multicolumn{1}{c}{ Factors } & DOF & $\begin{array}{c}\text { Sums of } \\
\text { Squares }\end{array}$ & Variance & F-Ratio & Pure Sum & Percent (P) \\
\hline (A) Aspect ratio & 3 & 100.155 & 33.385 & 75.347 & 98.464 & 72.23 \\
(B) Fiber Ratio & 3 & 8.554 & 2.851 & 7.638 & 6.863 & 5.04 \\
(C) W/C & 3 & 9.011 & 3.004 & 3.770 & 7.320 & 5.37 \\
(D) SF & 3 & 16.901 & 5.634 & 15.990 & 15.210 & 11.16 \\
Error & 3 & 1.691 & 0.564 & & & 6.20 \\
Total & 15 & 136.311 & & & & 100.00 \\
\hline
\end{tabular}

These quantities were calculated for Step 3. Total sum of squares compressive strength as follows.

Step 1. The sum of all S/N results (Table 5): $\quad S_{T}=\sum_{i=1}^{16} y_{i}^{2}-C F$

$$
\begin{aligned}
& T=35.518+ 34.189+35.974 \\
&+\cdots .+26.193=533.708
\end{aligned}
$$

Step 2. Correction factor:

$$
\begin{aligned}
& =\left(35.518^{2}+34.189^{2}\right. \\
& \left.+\cdots .+26.193^{2}\right)-17802.8 \\
& =330.8
\end{aligned}
$$

$$
C F=\frac{T^{2}}{n}=\frac{533.708^{2}}{16}=17802.8
$$

where $\mathrm{n}$ is the total number of experiments.

Step 4. Sum of squares of factors

$$
S_{A i}=\frac{S_{1}^{2}}{N_{A 1}}+\frac{S_{2}^{2}}{N_{A 2}}+\frac{S_{3}^{2}}{N_{A 3}}+\frac{S_{4}^{2}}{N_{A 4}}-C F
$$




$$
\begin{aligned}
A_{1}=A_{11}+A_{12} & +A_{13}+A_{14} \\
& =35.518+34.189 \\
& +35.974+34.529 \\
& =140.21
\end{aligned}
$$

$$
\begin{aligned}
A_{2}=A_{21}+A_{22} & +A_{23}+A_{24} \\
& =38.006+37.800 \\
& +35.509+37.356 \\
& =148.67
\end{aligned}
$$

$\mathrm{NA}_{1}, \mathrm{NA}_{2} \ldots=4$ (total number of experiments in which factor $\mathrm{A} 1, \mathrm{~A} 2 \ldots$ is present)

$$
\begin{aligned}
S_{A}=\frac{\sum_{1}^{4} A_{i}^{2}}{4}- & S_{T} \\
& =\frac{140.21^{2}+148.67^{2}+\cdots}{4} \\
& -330.8=185.38
\end{aligned}
$$

Step 5. Variance

$$
V_{A}=\frac{S_{A}}{D O F_{A}}=\frac{185.38}{3}=61.79
$$

Step 6. Pure sum of squares

$$
\begin{aligned}
S_{A}^{\prime}=S_{A}-\left(V_{e} x\right. & \left.D O F_{A}\right) \\
& =185.38-(1.776 \times 3) \\
& =180.05
\end{aligned}
$$

here $V e$ is the variance of error, DOFA is the degree of freedom of parameter $\mathrm{A}$

Step 7. Percentage contribution of parameters

$$
P_{A}=\frac{S_{A}^{\prime}}{S_{T}}=\frac{180.05}{330.8}=0.5443 \cong 54.53 \%
$$

\subsection{Estimating the Expected Performance $(\mathrm{S} / \mathrm{N})$ at Optimum Conditions}

The optimum conditions were calculated according to quality characteristics of "the bigger the better". As mentioned above, the optimum conditions for compressive strength and flexural strength are $A_{2}, B_{1}, C_{4}$ and $D_{2}$ (Table 9) and $\mathrm{A}_{4}, \mathrm{~B}_{4}, \mathrm{C}_{4}$ and $\mathrm{D}_{2}$ (Table 10) respectively. However, it can be seen from Table 5 that an experiment corresponding to optimum conditions was not performed during experimental work. Thus, the compressive and flexural strengths in the optimum conditions should be both estimated by equation 2 and verified by a confirmation experiment.

Table 9. The optimum conditions for compressive strength and prediction performance

\begin{tabular}{lcc}
\hline \multicolumn{1}{c}{ Factors } & Level & Contribution to the S/N \\
\hline (A) Aspect ratio & $\mathbf{A}_{2}(\mathbf{5 5})$ & 3.811 \\
(B) Fiber Ratio & $\mathbf{B}_{\mathbf{1}}(\mathbf{3 \%})$ & 3.253 \\
(C) W/C & $\mathbf{C}_{\mathbf{4}}(\mathbf{0 . 4 5})$ & 1.978 \\
(D) SF & $\mathbf{D}_{\mathbf{2}}(\mathbf{5 \%})$ & 1.724 \\
Total contribution of all factors $(\mathrm{S} / \mathrm{N})$ & 10.766 \\
The average performance statistics $(\mathrm{S} / \mathrm{N})$ & 33.357 \\
The expected value at optimum conditions $(\mathrm{S} / \mathrm{N})$ & 44.122 \\
Confirmation test results $(\mathrm{S} / \mathrm{N}) /(\mathrm{MPa})$ & $43.270 / 145.72$ \\
Confidence interval $(\alpha=95 \%)(\mathrm{S} / \mathrm{N})$ & $41.674-46.571$ \\
\hline
\end{tabular}


Table 10. The optimum conditions for flexural strength and prediction performance

\begin{tabular}{lcc}
\hline \multicolumn{1}{c}{ Factors } & \multicolumn{1}{c}{ Level } & Contribution to the S/N \\
\hline (A) Aspect ratio & $\mathbf{A 4}(\mathbf{8 0})$ & 1.809 \\
(B) Fiber Ratio & $\mathbf{B}_{\mathbf{4}}(\mathbf{1 2 \%})$ & 1.150 \\
(C) W/C & $\mathbf{C}_{\mathbf{4}}(\mathbf{0 . 4 5})$ & 1.253 \\
(D) SF & $\mathbf{D}_{\mathbf{2}}(\mathbf{5 \%})$ & 0.811 \\
Total contribution of all factors $(\mathrm{S} / \mathrm{N})$ & 5.022 \\
The average performance statistics $(\mathrm{S} / \mathrm{N})$ & 24.813 \\
The expected value at optimum conditions $(\mathrm{S} / \mathrm{N})$ & 29.835 \\
Confirmation test results $(\mathrm{S} / \mathrm{N}) /(\mathrm{MPa})$ & $29.98 / 31.58$ \\
Confidence interval $(\alpha=95 \%)(\mathrm{S} / \mathrm{N})$ & $28.456-31.22$ \\
\hline
\end{tabular}

The expected value of 44.123 at optimum conditions for compressive strength was calculated using equation 2 (Table 9).

$$
\begin{aligned}
\text { Exp. value }= & 33.357+(37.168-33.357) \\
& +(36.609-33.357) \\
& +(35.335-33.357) \\
& +(35.081-33.357) \\
& =44.122
\end{aligned}
$$

Then the confirmation experiment was performed at the optimum conditions and average of $145.72 \mathrm{MPa} \quad(43.270 \mathrm{~S} / \mathrm{N})$ compressive strength was obtained. Since this value is a point estimation, it should be determined whereas the results of the confirmation experiments are meaningful in a confidence interval of $95 \%$ using equation 3.

$$
\begin{aligned}
C I=44.122 \pm & \sqrt{\frac{10.128 \times 1,776}{3}} \\
& =44.122 \pm 2.448
\end{aligned}
$$

Since the result of confirmation experiment was between confidence interval, it can be said that the experimental results are meaningful at $95 \%$ confidence level.

\subsection{Effect of Aspect ratio}

The effect of aspect ratio on compressive and flexural strength is demonstrated in Figure 2 and 3 , respectively. The aspect ratio was obtained as the most important factor in concrete mix design for both compressive and flexural strengths (Table 9 and 10). Karadelis and Lin (Karadelis and Lin, 2015) indicated that the fiber aspect ratio has a remarkable influence on flexural performance. Wang et al. (Wang et al., 2010) emphasized that the effect of aspect ratio on mechanical properties of steel fiber reinforced concrete (SFRC) is significant and there is an optimal value for strength indexes in each concrete series. Therefore, the 2 nd level of 55 aspect ratio maximized the compressive strength (Figure 2 and Table 9). Bayramov et al. (Bayramov et al., 2004) performed a compressive and splitting tensile test for SFRC specimens. They concluded that the compressive strength increases with the increase in the aspect ratio. However, compressive strength declines when aspect ratio rises from 65 to 85 . Wang et al (Wang et al., 2010) concluded that although higher fiber aspect ratio induces lower compressive strength, the toughness and peak strain of SFRC increase. Similar results were obtained by Eren and Çelik (Eren and Celik, 1997). From the compressive strength results it is clear that increasing the 
aspect ratio decreases the workability, hence it causes difficulties in achieving good compaction of SIFCON matrix. Recent studies indicated that flexural strength increases with increasing aspect ratio (Yazıc1 vd., 2007; Teng et al., 2008). Therefore, the 4th level of 80 aspect ratio maximized the flexural strength (Figure 3 and Table 10).

\subsection{Effect of fiber ratio}

The 1st level of fiber ratio maximized the compressive strength (Figure 2 and Table 9). Farnam et al. compared SIFCON with high strength concrete (HSC) and highperformance fiber reinforced concrete (HPFRC) under confining pressure. They indicated that adding steel fiber up to $5 \%$ has a considerable effect on increasing triaxial compressive strength and adding more fiber has a small effect (Farnam et al., 2010). Similarly, in this study, a decrease in the compressive strength was observed as the fiber ratio increased. This is mainly due to the increase in voids because of segregation.

Using fiber in concrete increases both flexural strength and energy absorption capacity (Lankard, 1985; Ipek vd., 2014; Lee, 2017; Lee et al., 2017). Therefore, the 4th level of (12\%) fiber ratio maximized the flexural strength (Figure 3 and Table 10).

\subsection{Effect of $w / c$ ratio}

The effect of w/c on compressive and flexural strength are shown in Figure 2 and 3 respectively. From the test results, it can be seen that $0.45 \mathrm{w} / \mathrm{c}$ ratio maximizes both compressive and flexural strength. It is well known that as w/c ratio decreases the strength increases. Here, $0.30 \mathrm{w} / \mathrm{c}$ ratio is expected to maximize the strength. However, despite the benefits of fiber reinforcement, fiber can affect the workability of fresh concrete significantly. Moreover, concrete with mineral admixtures needs more water than others. Since, SF is extremely fine powders, the maximum compressive and flexural strength was obtained at $0.45 \mathrm{w} / \mathrm{c}$ ratio.

\subsection{Effect of SF}

Test results demonstrated that $5 \%$ SF replacement maximizes both compressive and flexural strength. It is known that adding mineral admixtures increase mechanical properties of concrete (Hinislioglu and Bayrak, 2004; Shah and Ribakov, 2011). However, very finely divided supplementary materials such as SF can have a very strong negative effect on water demand (Ikpong and Okpala, 1992; Erdoğan, 1997). Hence, workability reduces with increase in SF content.

\section{Conclusion}

Concrete pavements have been widely used in many countries due to its high load carrying capacity and low maintenance cost. The mission of concrete in a rigid pavement is to conduct the severe wheel load to the subgrade without any deformation. Passing a wheel load through the rigid pavement causes the compressive and flexural stresses. In this study, SIFCON which has high flexural strength was investigated as a rigid pavement. The Taguchi method was used for evaluating and optimization of four parameters each has four levels. The following conclusions can be drawn from this study:

- The optimum compressive strength was achieved by the second level of slenderness (55), the first level of fiber ratio $(3 \%)$, the fourth level of w/c (0.45) and the second level of SF ratio (5\%).

- The optimum flexural strength was achieved by the fourth level of slenderness (80), the fourth level of fiber ratio (12\%), the fourth level of w/c (0.45) and the second level of SF ratio (5\%).

- The compressive strength of $145.72 \mathrm{MPa}$ was obtained with 55 aspect ratio in optimum conditions. 
- Reduction in compressive strength was determined as fiber aspect ratio $(\mathrm{L} / \mathrm{d})$ increases.

- Reduction in compressive strength was determined as fiber volume increases.

- The aspect ratio (L/d) was determined as the most effective parameter on both compressive and flexural strength.

- The flexural strength of $31.58 \mathrm{MPa}$ was obtained with 80 aspect ratio in optimum conditions.

- The increment in compressive strength was determined as fiber volume increases.

- It was determined that the most and less effective parameter on both compressive and flexural strengths were the aspect ratio and SF content respectively.

\section{References}

Abdou, H. M., Naaman, A. E.,Wight, J. K. 1989. Cyclic response of reinforced concrete connections using cast-inplace sifcon matrix (No. UMCE 89-1).

ACI, C. 1996. "State-of-the-art report on fiber reinforced plastic (FRP) reinforcement for concrete structures. Closure", Aci Structural Journal, 93(1), 151-151.

Bayrak, O. U., Hinislioglu, S. 2017. "A new approach to the design of rigid pavement: single axle loading. Road Materials and Pavement Design,18(3), 573-589.

Bayramov, F., Taşdemir, C.,Taşdemir, M. 2004. "Optimisation of steel fibre reinforced concretes by means of statistical response surface method", Cement and Concrete Composites, 26(6), 665-675.

Beglarigale, A., Yalçınkaya, Ç., Yiğiter, H.,Yazıc1, H. 2016. "Flexural performance of SIFCON composites subjected to high temperature", Construction and Building Materials, 104, 99-108.

Bingöl, M. Z. 2017. "Optimization of Compressive and Flexural Strength of Concrete Pavements Produced with SIFCON". Unpublished MSc Thesis, Ataturk University Graduate School of Natural and Applied Science.

Chan, Y. W.,Chu, S. H. 2004. "Effect of silica fume on steel fiber bond characteristics in reactive powder concrete", Cement and Concrete Research, 34(7), 11671172.

Erdoğan, T. Y. 1997. "Admixtures for concrete".Middle East Technical University Press.

Eren, Ö.,Celik, T. 1997. "Effect of silica fume and steel fibers on some properties of high-strength concrete", Construction and Building Materials, 11(7-8), 373382.

Farnam, Y., Moosavi, M., Shekarchi, M., Babanajad, S.,Bagherzadeh, A. 2010. "Behaviour of slurry infiltrated fibre concrete (SIFCON) under triaxial compression", Cement and Concrete Research, 40(11), 1571-1581.

Hinislioglu, S.,Bayrak, O. U. 2004. "Optimization of early flexural strength of pavement concrete with silica fume and fly ash by the Taguchi method", Civil Engineering and Environmental Systems, 21(2), 79-90.

Hinislioglu, S.,Bayrak, O. U. 2005. "A robust approach for evaluating modulus of elasticity of pavement concrete", Indian Journal of Engineering and Materials Sciences, 12(2), 111-116.

Ikpong, A.,Okpala, D. 1992. "Strength characteristics of medium workability ordinary Portland cement-rice husk ash 
concrete", Building and Environment, 27(1), 105-111.

Ipek, M., Aksu, M., Yilmaz, K.,Uysal, M. 2014. "The effect of pre-setting pressure on the flexural strength and fracture toughness of SIFCON during the setting phase", Construction and Building Materials, 66, 515-521.

Karadelis, J. N.,Lin, Y. 2015. "Flexural strengths and fibre efficiency of steelfibre-reinforced, roller-compacted, polymer modified concrete", Construction and Building Materials, 93, 498-505.

Lankard, D. R. 1984. "Slurry infiltrated fiber concrete (SIFCON): Properties and applications", MRS Online Proceedings Library Archive, 42.

Lankard, D. R. 1985. Preparation, properties and applications of cement-based composites containing 5 to 20 percent steel fiber. Paper presented at the Steel Fibre Concrete US-Sweden joint seminar, Stockholm, Ed. by Shah, SP and Skarendahl, A.(June 1985).

Lankard, D. R.,Newell, J. K. 1984. "Preparation of highly reinforced steel fiber reinforced concrete composites", Special Publication, 81, 287-306.

Lee, J.-H. 2017. "Influence of concrete strength combined with fiber content in the residual flexural strengths of fiber reinforced concrete", Composite Structures, 168, 216-225.

Lee, J.-H., Cho, B.,Choi, E. 2017. "Flexural capacity of fiber reinforced concrete with a consideration of concrete strength and fiber content", Construction and Building Materials, 138, 222-231.

Mehta, P. K. 1986. "Concrete. Structure, properties and materials".
Musmar, M. 2013. "Tensile strength of steel fiber reinforced concrete", Contemporary Engineering Sciences, 6(5), 225-237.

Neville, A. M. 1995. "Properties of concrete", (Vol. 4).Longman London.

Rao, H. S., Ghorpade, V. G., Ramana, N.,Gnaneswar, K. 2010. "Response of SIFCON two-way slabs under impact loading", International Journal of Impact Engineering, 37(4), 452-458.

Richard, P.,Cheyrezy, M. 1995. "Composition of Reactive Powder Concretes", Cement and Concrete Research, 25(7), 15011511.

Roy, R. 1990. "A primer on the Taguchi method, competitive manufacturing series", New York, 7-80.

Shah, A. A.,Ribakov, Y. 2011. "Recent trends in steel fibered high-strength concrete", Materials \& Design, 32(8), 4122-4151.

Taguchi, G. 1962. "Tables of orthogonal arrays and linear graphs", Maruzen, Tokyo.

Teng, T.-L., Chu, Y.-A., Chang, F.-A., Shen, B.-C.,Cheng, D.-S. 2008. "Development and validation of numerical model of steel fiber reinforced concrete for high-velocity impact", Computational Materials Science, 42(1), 90-99.

Tuyan, M.,Yazıc1, H. 2012. "Pull-out behavior of single steel fiber from SIFCON matrix", Construction and Building Materials, 35, 571-577.

Wang, Z., Wu, J.,Wang, J. 2010. "Experimental and numerical analysis on effect of fibre aspect ratio on mechanical properties of SRFC", Construction and Building Materials, 24(4), 559-565. 
Yazıc1, Ş., İnan, G.,Tabak, V. 2007. "Effect of aspect ratio and volume fraction of steel fiber on the mechanical properties of SFRC", Construction and Building Materials, 21(6), 1250-1253. 